\title{
Perancangan Komik Online tentang Cara Menggunakan Media Sosial dengan Bijak pada Remaja Usia 15-17 Tahun
}

\author{
Natasyia Sisca Eka Pratiwi, Diana Aqidatun Nisa, dan Aditya Rahman Yani \\ Program Studi Desain Komunikasi Visual, Fakultas Arsitektur dan Desain, \\ Universitas Pembangunan Nasional "Veteran" Jawa Timur, Surabaya, Indonesia \\ e-mail: 17052010026@student.upnjatim.ac.id
}

\begin{abstract}
Abstrak-Remaja adalah fase perkembangan dari anak-anak ke arah kedewasaan. Dalam perkembangannya, remaja berkaitan erat dengan bagaimana mereka bersosialisasi bersama teman sebaya di media sosial (Instagram, Twitter, dan Facebook) dengan cara mengirim pesan, upadate status, komentar postingan dan membagikan postingan. Permasalahan utama dari remaja hari ini adalah tentang kebiasaan mengupload konten sensitif yang menyinggung SARA dan melanggar UU ITE hanya demi menaikkan popularitas pribadi. Disamping itu, kecenderungan remaja saat ini suka membuat konten saling sindir di media sosial. Makalah ini membahas bagaimana merancang komik online tentang etika menggunakan media sosial secara bijak, untuk remaja usia 15 17 tahun. Metode yang digunakan untuk mengumpulkan data penelitian yaitu dengan menggunakan kuesioner, observasi dan wawancara mendalam. Teknik analisis yang digunakan dalam penelitian ini adalah teknik analisa deskriptif kualitatif menurut Milles dan Huffman. Dari proses analisis data tersebut maka, telah didapatkan keyword "Batasan berekspresi dan berkomunikasi di media sosial" yang menjadi dasar konsep cerita dan konsep visual dalam perancangan komik online ini. Dengan adanya komik online ini, diharapkan dapat meningkatkan kesadaran remaja terhadap etika menggunakan media sosial secara bijak, dan meningkatkan minat remaja untuk membuat konten positif di media sosial.
\end{abstract}

Kata Kunci-perancangan, komik online, media sosial, bijak, dan remaja.

\footnotetext{
Abstract-Adolescence is a phase of development from childhood to maturity. In their development, adolescents are closely related to how they socialize with peers on social media (Instagram, Twitter, and Facebook) by sending messages, updating status, posting comments, and sharing posts. The main problem of teenagers today is the habit of uploading sensitive content that offends SARA and violates the ITE Law just to increase their popularity. Besides that, the tendency of teenagers today to make satire content on social media. This paper discusses how to design online comics about ethics in using social media wisely, for adolescents aged 15-17 years. The method used to collect research data is by using a questionnaire, observation, and in-depth interviews. The analysis technique used in this study is a qualitative descriptive analysis technique according to Milles and Huffman. From the data analysis process, the keyword "Limits of expression and communication on social media" has been obtained, which is the basis for the concept of stories and visual concepts in designing this online comic. With the existence of this online comic, it is hoped that it can increase adolescent awareness of the ethics of using social media wisely and increase teenagers' interest in creating positive content on social media.
}

Keywords-design, online comic, social media. wise, and teenagers.

\section{PENDAHULUAN}

Masa remaja identik dengan mencari jati diri, mencari perhatian, mencari koneksi atau teman dan mudah dipengaruhi teman sebaya dan lingkungannya [1]. Dalam kesehariannya remaja tak lepas dari media sosial dan internet yeng berfungsi sebagai sumber informasi, media hiburan dan media untuk berkomunikasi dengan teman sebaya melalui media sosial. Menurut Asosiasi Penyelenggara Jasa Internet Indonesia (APJJI) pada tahun 2020 kuartal $\mathrm{Q}_{2}$, mayoritas pengguna internet adalah remaja dengan usia 15-19 tahun sekitar 8,29\% dan 10-14 tahun sekitar 8,31\% [2].

Menurut Peg Strep seorang pemerhati digital, penyebab remaja mengakses media sosial yaitu remaja ingin mendapatkan perhatian melalui media sosial, meminta apresiasi berupa like, coment retweet sehingga dapat meningkatkan rasa percaya diri dan popularitas remaja, menumbuhkan citra yang terlihat baik di dunia maya dan sebagai pedoman hidup bersosialisasi sehingga sulit berpaling ke dunia nyata [3].

Media sosial merupakan media online yang memungkinkan para pengguna untuk saling terhubung, berkomunikasi berpartisipasi dan menciptakan konten dari media yang telah digunakan secara berama-sama oleh penggunanya. Namun fasilitas di media sosial memungkinkan remaja menyalagunakan media sosial seperti membuat konten sensitif, konten saling ejek, bebas berkomentar dan menyalurkan pendapat tanpa ada rasa khawatir di media sosial demi mendapatkan banyak like dan komentar di media sosial yang dapat berakibat fatal bagi diri sendiri. Contoh kasus pada aksi remaja SMA joget tik tok pada gerakan shalat [4]. Aksi tersebut secara langsung melanggar UU ITE pasal 28 yang melarang adanya perilaku orang yang sengaja membuat dan menyebarkan konten/informasi yang menimbulkan rasa kebencian individu, kelompok masyarakat tertentu yang berdasarkan ras, agama dan antar golongan [5].

Untuk menyelesaikan masalah tersebut, telah dibuat media literasi edukasi untuk mengajak remaja menggunakan media sosial dengan bijak, seperti contohnya ebook yang dapat diakses seara online melalui portal website literasidigital.id/ dan www2.slideshare.net/. Akan tetapi menurut hasil kuesioner, yang disebarkan kepada 127 
responden, sekitar 58,6\% responden tidak mengetahui ebook tentang cara menggunakan media sosial dengan bijak, sekitar $26 \%$ remaja belum menggunakan media sosial dengan bjak dan sekitar 53,5 \% kadang-kadang menemukan konten sensitif ujaran kebencian dan konten sejenisnya. Oleh karena itu diperlukan media edukasi yang dekat dan mudah diakses untuk remaja.

Komik merupakan media edukasi alternatif yang dapat dipilih karena komik media yang sederhana, yang dapat memuat pesan menjadi lebih ringkas melalui bentuk cerita, mudah dicerna dan dilengkapi bahasa verbal yang bersifat dialogis [6]. Komik online (webcomic) adalah jenis komik yang dietrbitkan secara mandiri melalui media sosial seperti Facebook, Twiter atau Tumblr [7].

Menurut hasil kuesioner pra perancangan sekitar 37,8\% remaja menyukai komik online karena memuat gaya gambar berwarna, sekitar $16,7 \%$ remaja berpendapat komik online memuat cerita yang lebih menarik dan sekitar $28,9 \%$ remaja berpendapat komik online mudah diakses dari pada media literasi lainnya. 68,9\% remaja juga cenderung menyukai komik gaya gambar jepang (manga) yang sederhana dan berwarna. Sehingga konsep perancangan ini akan menggunakan pendekatan style yang disukai remaja yaitu gaya gambar komik sederhana perpaduan jepang, manhwa dan indonesia, pendekatan cerita edukasi dengan gendre slice of life, comedy dan romance dengan memberikan kesan emosional kepada pembaca tentang dampak yang didapatkan bila menguupload konten sensitif di media sosial.

\section{METODE}

Pada perancangan komik online tentang cara menggunakan media sosial dengan bijak, beberapa tahapan dilakukan sebagai berikut:

\section{Menemukan permasalahan desain}

Tahapan awal dalam perancangan ini adalah menemukan permasalahan desain. Melalui studi literatur dan pencarian data maupun fakta suatu objek baik bersifat positif maupun bersifat negatif. Pada perancangan ini permasalahn yang ditemukan adalah masih ada remaja yang belum menggunakan media sosial dengan bijak dengan membuat status melanggar UU ITE untuk menaikkan popularitas.

\section{Hipotesis sementara}

Setelah menemukan permasalahan, maka perancang menentukan dugaan yang terkait dengan permasalahan tersebut. Hipotesis sementara dalam perancangan ini adalah remaja masih belum mengetahui pentingnya menggunakan media sosial dengan bijak.

\section{Menentukan tujuan dan manfaat}

Adalah kegiatan untuk menyusun masalah yang akan diangkat dalam perancangan ini. Pada perancangan ini, masaah yang diangkat yaitu masih ada remaja yang belum menggunakan media sosial dengan bijak dan media edukasi yang membahas media sosial adalah literasi digital yang tidak dekat dengan remaja.

\section{Studi eksisting, studi komparator dan studi kompetitor}

Merupakan tahapan mencari acuan, menentukan dan melakukan analisa kajian objek yang akan dikembangkan dan dijadikan studi eksisting, komparator dan studi kompetitor sebagai perbandingan output perancangan. Pada perancangan ini studi eksisting, studi komparator dan studi kompetitor yang diimplementasikan yaitu buku literasi digital cakap bermedia sosial yang dapat diakses di https://literasidigital.id/, komik online joyfull delight dan komik online geneasi sosmed yang dapat diakses di LINE Webtoon.

\section{Tahap pengumpulan data}

Pada tahapan ini merupakan proses untuk mengumpulkan data baik data yang bersifat kuantitatif maupun kualitatif melalui sumber-sumber yang terkait. Data-data primer dan sekunder diperoleh sebagai berikut.

\section{Data primer}

Data primer adalah data yang didapatkan pengumpul data yang berasal dari sumber data secara langsung [8]. Metode pngumpulan data primer menggunakan metode wawancara, observasi dan pemberian pertanyaan kuosioner secara langsung kepada target audiens dan narasumber utama.

Aktivitas berikut untuk mendapatkan data primer dari beberapa sumber:

a. Wawancara yang dilakukan dengan psikolog Ibu Wanda Rahma Syanti, M. Psi yang aktif sebagai piskolog dan dosen pendidikan strata 1 jurusan Psikologi Universitas Hang Tuah Surabaya Jawa Timur. Wawancara dilakukan untuk mengumpulkan informasi tentang karakteristik remaja dengan media sosial dan menggali pendekatan edukasi yang tepat untuk remaja.

b. Wawancara yang dilakukan dengan Mas Aan Setiawan Aditnya, seorang author komik webtoon official "Reset". Wawancara dilakukan untuk mengumpulkan informasi tentang beberapa teknis menggambar komik online, pasar dunia komik online dan karakteristik komik online yang baik. c. Wawancara yang dilakukan dengan Mira Aulia Alamanda, seorang siswi remaja SMA yang gemar membaca komik online dan selalu rutin membaca webtoon setiap minggunya di layanan LINE Webtoon. Wawancara dilakukan untuk mengumpulkan informasi tentang karakteristik komik webtoon yang menjadi favorit remaja perempuan.

d. Wawancara yang dilakukan dengan Hizamsya Cheva Ma'rufano, seorang siswa remaja SMA yang gemar membaca komik online dan sering membaca webtoon dan komik strip online setiap minggunya di layanan LINE Webtoon dan instagram. Wawancara dilakukan untuk mengumpulkan informasi tentang karakteristik webtoon yang menjadi favorit remaja laki-laki.

e. Observasi layanan playfrom aplikasi komik online pada bulan November 2020 dengan mengunjungi situs Google Playstore untuk melihat review tingkat kepuasan pembaca dalam membaca komik online.

f. Menyebarkan 100 kuesioner Pra Perancangan pada target Audiens pada Bulan Oktober 2020 untuk mengetahui keseharian dan pendapat remaja tehadap media sosial sebagai acuan desain komik bijak menggunakan media sosial.

g. Menyebarkan 100 kuesioner Perancangan pada target Audiens pada Bulan Desember 2020 untuk mengetahui karakteristik media literasi yang menjadi favorit remaja. 


\section{Data Sekunder}

Data sekunder meliputi data dari internet, jurnal dan literatur yang telah dipublikasikan.

\section{Buku}

1. Buku "Understanding Comic" karya Scott Mc Cloud tahun 1993. Buku ini sebagai dasar untuk mendapatkan informasi tentang tahapan membuat komik dan metode merancang komik..

2. Buku "Membuat Komik" oleh Scott Mc Cloud tahun 2008. Buku ini digunakan untuk mendapatkan informasi mengenai tahapan cara membuat komik, dan unsur- unsur yang membangun komik.

3. Ebook "Cakap Bermedia sosial remaja" tahun 2016 oleh Ditjen IKP, Kominfo untuk mendapatkan informasi cara mengunakan media sosial dengan bijak untuk remaja.

4. Ebook "Bijak bersosmed " tahun 2017 Gerakan Bijak Bersosmed dan Indosat Ooredoountuk mendapatkan informasi tambahan cara mengunakan media sosial dengan bijak untuk remaja.

\section{Jurnal}

1. Felita dkk, 2016, Jurnal Ilmiah Psikologi : Pemakaian Media Sosial dan Self Concept Pada Remaja : Universitas Khatolik Indonesia

2. Putri dkk, 2016, Jurnal Volume 3 : Pengaruh Media Sosial Terhadap Perilaku Remaja: Prosiding Ks:Riset \& PKM

\section{Komik Online}

Komik online "Generasi Sosmed" karya Tisa Ashifa yang dimuat LINE Webtoon sebagai sumber inspirasi cara mengemas konten media sosial dalam sebuah komik.

\section{Analisis data}

Tahapan ini merupakan proses untuk mengatur urutan data, mengelompokkan dan merumuskan data yang telah didapatkan dari proses pengumpulan data. Metode analisis yang digunakan adalah metide analisis deskriptif kualitatif Miles dan Huffman yaitu adalah metode untuk menyimpulkan suatu data, kemudian memilah data-data tersebut menjadi satuan konsep tertentu, kategori tertentu dan tema tertentu [9].

\section{Hasil Pengumpulan data.}

a. Hasil wawancara dengan psikolog Ibu Wanda Rahma Syanti, M. Psi., Poin-poin hasil wawancara tersebut antara lain:

1. Remaja yang masih di usia labil memiliki rasa penasaran tinggi. Hal ini terjadi karena remaja dalam proses pencarian identitas, yang psikologisnya dipengaruhi teman sebaya (peer group) dan lingkungannya

2. Pengawasan orang tua pada remaja dalam menggunakan media sosial dapat berupa diskusi dua arah Keluarga terdekat atau teman terdekat juga dapat memberikan gambaran secara langsung mengenai dampak positif dan negatif dari mengupload konten di media sosial

3. Media literasi yang cocok dengan remaja adalah penyampaian gambaran/ studi kasus mengenai dampak media sosial kepada remaja, disertai poinpoin singkat dalam bentuk infografis, penampilan diagram, gambar yang menarik, dengan bahasa persuasif.

b. Hasil wawancara dengan Author Webtoon Reset, Aan Setiawan Aditnya. Poin- poin hasil wawancara tersebut antara lain:

1. Pembaca Komik Webtoon mayoritas masyarakat muda dengan rentang pendidikan SMP- Kuliah. Untuk membuat cerita webtoon kita harus mengetahui apa yang disukai pembaca dan melakukan riset untuk membuat cerita yang baik. Untuk tren baca webtoon saat ini, banyak pembaca yang menyukai gendre romance dibandingkan gendre lainnya.

2. Komik webtoon baik dan efektif sebagai media edukasi. Namun harus disertai tagline "edukasi" untuk terus membatasi ruang gerak author dalam berkarya.

c. Hasil wawancara dengan target audiens remaja SMA perempuan yang gemar membaca komik online, Mira Aulia Alamanda. Poin-poin hasil wawancara tersebut antara lain:

1. Dalam membaca komik online, bagian pertama yang dilihat pembaca adalah ilustrasi gambar yang ditampilkan. Bila ilustrasinya menarik maka pembaca mencoba membaca komik online tersebut. Faktor kedua adalah menentukan komik yang akan dibaca adalah jika tampilan gambar komik yang standar namun cerita lebih menarik maka pembaca juga membaca komik tersebut.

2. Pembaca remaja lebih suka komik online daripada media lainnya karena komik online memliki cerita dalam bentuk visual yang menarik dan berwarna. Pembaca sangat antusias komik online, biasanya pembaca menunggu episode atau mendownload episode bila episode sudah rilis sehingga komik online dapat dibaca kapan saja tanpa terhubung dengan internet.

d. Hasil wawancara dengan target audiens remaja SMA perempuan yang gemar membaca komik online, Mira Aulia Alamanda. Poin-poin hasil wawancara tersebut antara lain:

1. Dalam membaca komik online, bagian pertama yang dilihat pembaca adalah ilustrasi gambar yang ditampilkan. Bila ilustrasinya menarik maka pembaca mencoba membaca komik online tersebut. Faktor kedua adalah menentukan komik yang akan dibaca adalah jika tampilan gambar komik yang standar namun cerita lebih menarik maka pembaca juga membaca komik tersebut.

2. Pembaca remaja lebih suka komik online daripada media lainnya karena komik online memliki cerita dalam bentuk visual yang menarik dan berwarna. Pembaca sangat antusias komik online, biasanya pembaca menunggu episode atau mendownload episode bila episode sudah rilis sehingga komik online dapat dibaca kapan saja tanpa terhubung dengan internet.

e. Hasil wawancara dengan target audiens remaja SMA lakilaki yang gemar membaca komik online, Hizamsya Cheva Ma'rufano poin-poin hasil wawancara tersebut antara lain:

1. Pembaca remaja laki laki lebih suka komik online karena komik mudah diakses melalui smartphone dan cara membaca komik yang simpel. Untuk selera hizam sendiri, lebih menyukai komik online daripada komik cetak dan bukan tipe pengloleksi komik cetak. 
2. Dalam membaca komik online, bagian pertama yang dilihat pembaca adalah sinopsis komik. Bila gambar komik standrat (biasa saja) namun cerita menarik, pembaca akan membaca webtoon tersebut.

f. Hasil kuesioner yang disebarkan kepada 100 target audiens sebagai berikut:

1. Remaja mayoritas mengakses media sosial untuk keperluan hiburan dengan persentase sebesar 52,2\% dan mencari informasi $25,2 \%$ dan sekitar $12,6 \%$ untuk berkomunikasi.dan sebesar $58,3 \%$.

2. Remaja mayoritas tidak mengetahui literasi digital ebook sebesar Berdasarkan data ini, literasi digital ebook merupakan media yang tidak dekat dengan remaja

3. Sebesar $26 \%$. remaja merasa belum menggunakan media sosial dengan bijak. remaja sekitar 58,6\% responden tidak mengetahui ebook tentang cara menggunakan media sosial dengan bijak

4. Dari riset kuesioner $75,7 \%$, remaja menyukai komik webtoon, alasan remaja menyukai komik webtoon, yaitu $37,8 \%$ komik online memuat gaya gambar berwarna, $16,7 \%$ memuat cerita lebih menarik dan sekitar $28,9 \%$ komik online adalah media yang mudah diakses.

5. Dari riset kuesioner, remaja menyukai genre comedy $54 \%$, romance $50 \%$ dan genre slice of life $44 \%$.

g. Hasil observasi melalui google playstore untuk mengetahui tanggapan pembaca dalam membaca komik online sebagai berikut:

1. Beberapa layanan aplikasi baca komik online sudah tersedia di google playstore seperti We-comic, Line Webtoon dan Mangatoon.

2. Masyarakat sangat antusias membaca komik online dan mendukung industri komik online. Hal ini dilihat dengan adanya rating LINE Webtoon mencapai 4.6 dan banyak ulasan positif dan masukan tentang aplikasi komik LINE Webtoon agar semakin berkembang.

\section{Kesimpulan}

Berdasarkan hasil analisis yang telah dilakukan dapat disimpulkan yaitu remaja memerlukan informasi tentang cara menggunakan media sosial dengan bijak dalam bentuk media literasi yang mudah diakses, mudah dipahami, dengan penggambaran visual yang menarik, sedikit teks dengan penambahan poin-poin data dan fakta.

\section{HASIL DAN PEMBAHASAN}

\section{Konsep Kreatif}

Keyword dalam perancangan ini adalah "Batasan berekspresi dan berkomunikasi di media sosial " yang terdiri dari kata "batasan", "berekspresi" dan "berkomunikasi di media sosial". Makna denotatif kata batasan dalam keyword tersebut adalah ketentuan yang tidak boleh dilampaui, dan makna denotatif kata "berekspresi" adalah mengungkapan atau proses menyatakan dengan memperlihatkan atau menyatakan maksud, gagasan, perasaan. Makna denotatif kata "berkomunikasi" adalah kegiatan melaksanakan komunikasi/ berhubungan dan makna denotatif kata "media sosial" adalah media online/daring yang digunakan oleh pengguna untuk saling berpartisipasi, berbagi, berinteraksi, menciptakan isi blog dan jejaring sosial di dunia virtual tanpa dibatasi oleh ruang dan waktu [10]. Sedangkan Makna konotatif yang tekandung dalam keyword "berekspresi" dan "berkomunikasi di media sosial" yaitu adanya batasan dalam berekpresi ketika bercerita dan membuat konten di media sosial dan batasan dalam menanggapi konten di media sosial. Melalui keyword tersebut, perancang ingin menyampaikan pentingnya berhatihati saat menggunakan media sosial (Gambar 1).

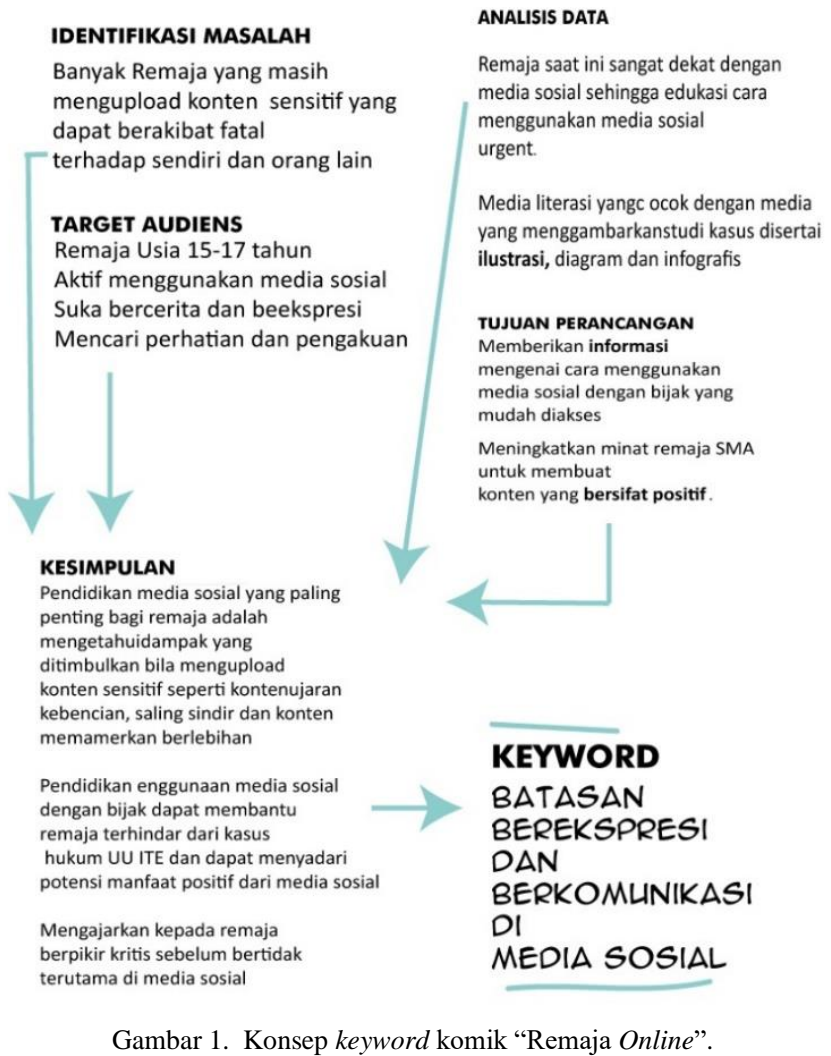

Konsep Verbal

Gaya bahasa

Pada perancangan ini, bahasa yang dipilih adalah Bahasa Indonesia yang santai yang sering digunakan remaja.

\section{Judul}

Judul dari komik yang dirancang adalah "Remaja online" yang memiliki makna permasalahan remaja yang masih belum menggunakan media sosial dengan bijak.

\section{Konsep cerita}

Konsep cerita/storyline perancangan komik online ini terinspirasi dari kasus viral berita di media sosial. Komik secara keseluruhan terdiri dari 15 chapter dengan 3 cerita yang berbeda yang terinspirasi dari kasus viral pelanggaran media sosial dan beberapa literasi:

1. Pada chapter 1-5 membahas tentang dampak mengupload konten negatif yang menyinggung SARA,

2. Chapter 6-10 bercerita tentang dampak bila bersikap implusif (menyalurkan marah, emosi dan kesal) di media sosial dengan berkomentar buruk/ saling menjatuhkan melalui media sosial.

3. Dan chapter 10-15 memuat cerita dampak mengupload konten/status yang mengumbar kekesalan yang berakibat dapat memberikan citra buruk di media sosial. 


\section{Konsep Visual}

Gaya gambar

Gaya gambar yang dipilih adalah gaya Jepang. Dalam komik online ini juga ditambahkan beberapa unsur budaya Indonesia untuk menggambarkan keseharian remaja di Indonesia (Gambar 2).

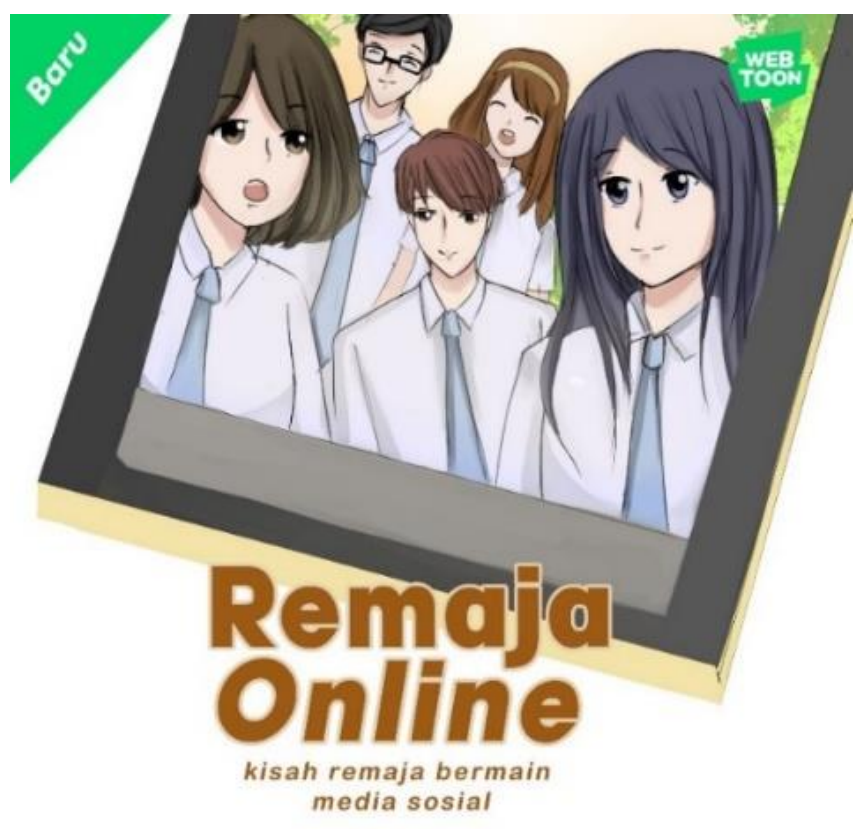

Gambar 2. Cover komik "remanja online".

Gaya tersebut dipilih agar dapat mempermudah audiens untuk memahami pesan moral yang akan disampaikan dalam komik online dan menambah daya tarik baca remaja yang karakteristiknya menyukai media yang sederhana (simple) dengan warna cerah, pastel dan warna yang mengandung unsur semangat yang tidak suram.

\section{KONSEP WARNA}

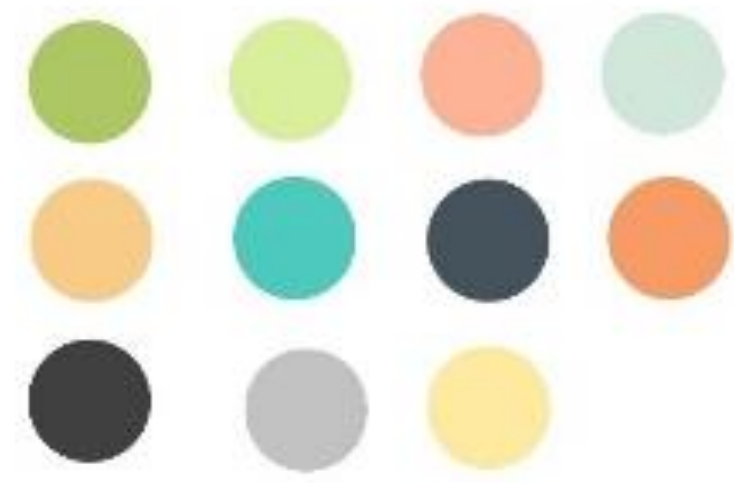

Gambar. 3. Acuan warna komik "Remaja Online"

\section{Acuan warna}

Warna yang diterapkan identik dengan warna pastel dan warna cerah dapat merepresentasikan kesan segar, ramah, dan semangat untuk remaja (Gambar 3).

\section{Layout komik}

Komik tersusun secara vertikal dengan cara membaca scrolling dari atas ke bawah. Pada bagian komik online ini terdiri dari beberapa bagian yaitu cerita komik, pelajaran yang dapat diambil dan tips-tips cara menggunakan media sosial. Bagian cerita komik digambarkan cerita komik yang tersusun dari beberapa panel secara memanjang vertikal seperti dapat dilihat pada Gambar 4.

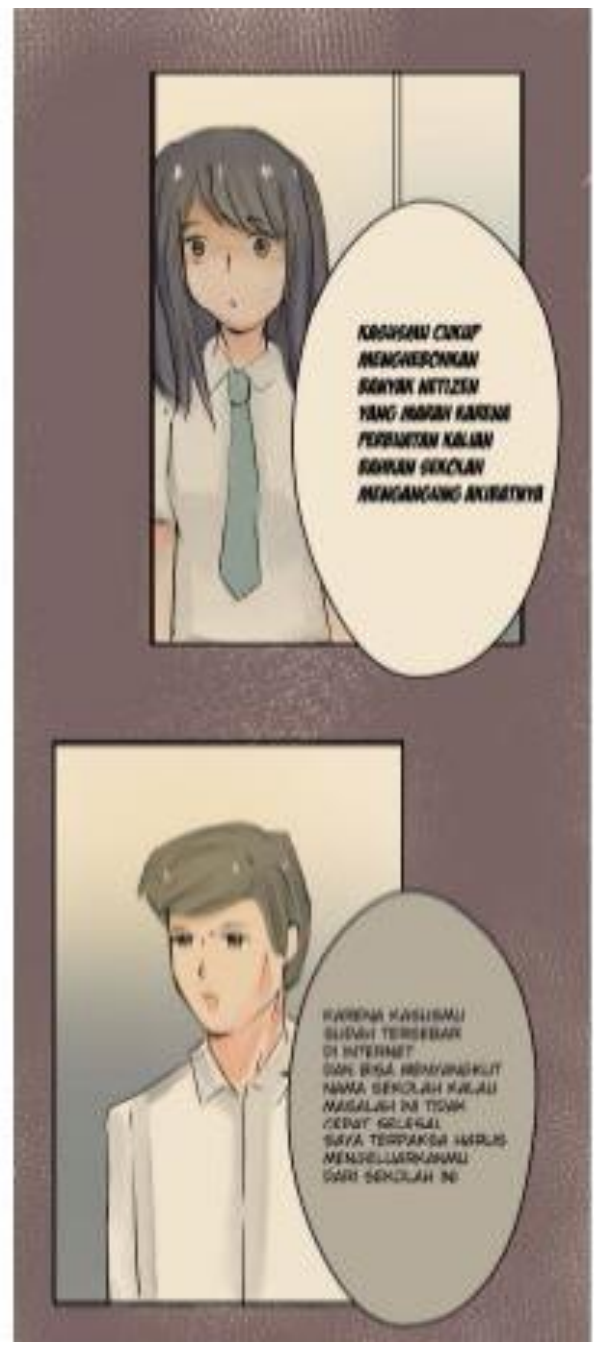

Gambar 4. Panel komik "Remaja Online"

Bagian balon kata berwarna kuning merupakan nilai pelajaran yang dapat diambil pada cerita komik yang sedang disampaikan (Gambar 5).

Pada tiap bagian episode akhir cerita juga terdapat poin-poin tips cara menggunakan media sosial yang bisa dipraktekkan remaja pada kehiduan sehari-hari, seperti dapat dilihat pada Gambar 6.

\section{Tipografi komik}

Pada perancangan komik online ini, penggunaan tipografi Anime Ace dipilih karena ukuran tipografi ini besar dan memiliki tingkat keterbacaan yang tinggi (Gambar 7).

\section{Tipografi Judul Komik}

Judul komik online ini, menggunakan tipografi provicali jenis huruf ini dipilih karena, jenis huruf ini memiliki bentuk huruf yang tebal, kesan, santai dan mudah dibaca sehingga huruf ini cocok sebagai pemilihan judul cover komik (Gambar 8). 


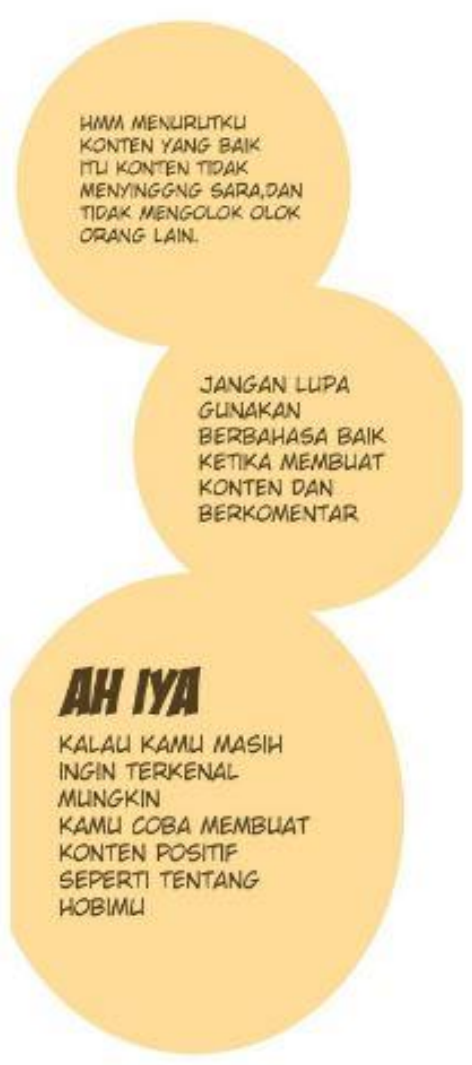

Gambar 5. Bagian nilai pelajaran komik online.

\section{TIPS MENGLINAKAN MEDIA SOSIAL (1)}
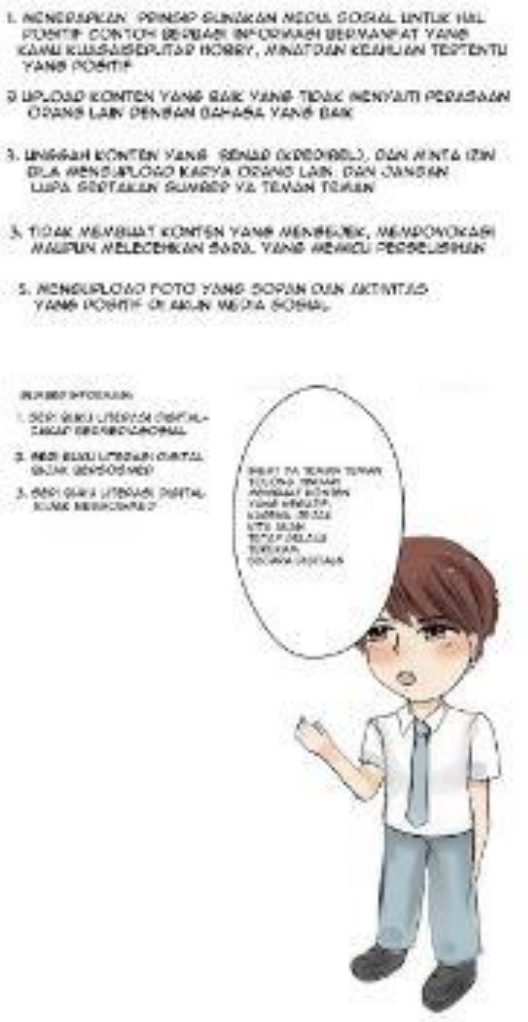

Gambar. 6. Tips-tips cara menggunakan media sosial di komik "Remaja Online".

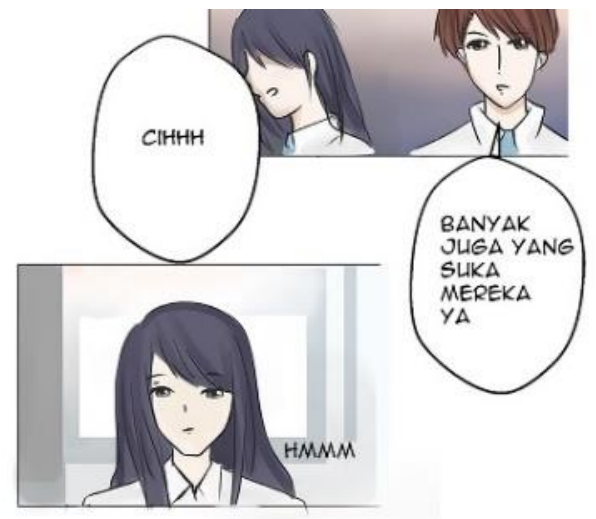

Gambar 7 Font Anime ace pada komik "Remaja Online"

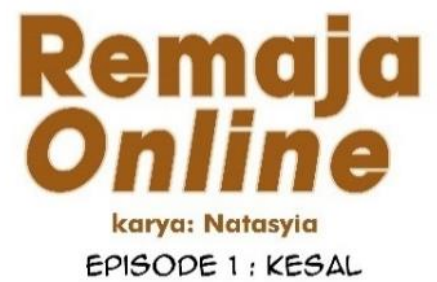

Gambar 8. Font Provicalli pada judul komik online.

\section{Tokoh komik}

Tokoh komik ini terdiri dari 5 orang remaja yaitu Tiara, Anna, Amy, Setya dan Andi yang digambarkan remaja Indonesia yang hidup dekat dengan internet. Beberapa karater tokoh komik online yaitu Tiara memiliki sifat ingin terkenal, iri hati. Anna memiliki sifat mudah cemburu, iri hati dan kalem. Amy memiiki sifat kalem namun merasa mudah tersaingi. Andi memiliki sifat bijaksana dan Setya yang memiliki sifat santai, ramah dan cerewet. Setiap permasalahan cerita memiliki tokoh utama yang berbeda (Gambar 9).

Bagian tokoh utama pada setiap cerita yaitu Tiara sebagai tokoh utama cerita komik online chapter 1-5, Anna sebagai tokoh utama cerita komik online chapter 6-10, Amy sebagai tokoh utama cerita komik online chapter $11-15$.
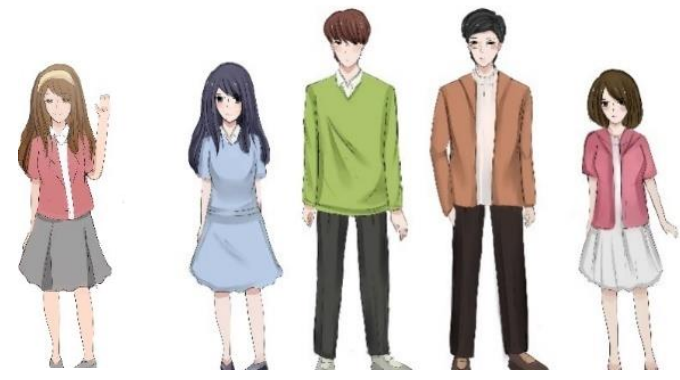

Gambar 9. Tokoh komik "Remaja Online": Tiara, Anna, Setya, Andi, dan Amy.

\section{Konsep Media}

Media utama

1. Komik onine yang dipublikasikan di layanan LINE Webtoon canvas yang dapat diakses pada link https://s.id/Bvz5Q

2. Ukuran komik 700 px x 10.000px dan resolusi 300 dpi

3. Komik online berwarna terdiri dari sekitar 15 chapter dengan 3 jenis cerita yang berbeda 
4. Judul komik bernama "Remaja Online"

5. Komik online rilis setiap hari minggu

\section{Media pendukung}

1. Media promosi akun instagram komik "Remaja Online" Merupakan media pendukung yang bertujuan untuk mengupload informasi preview chapter komik online yang terbaru yang telah di upload di layanan LINE Webtoon (Gambar 10).

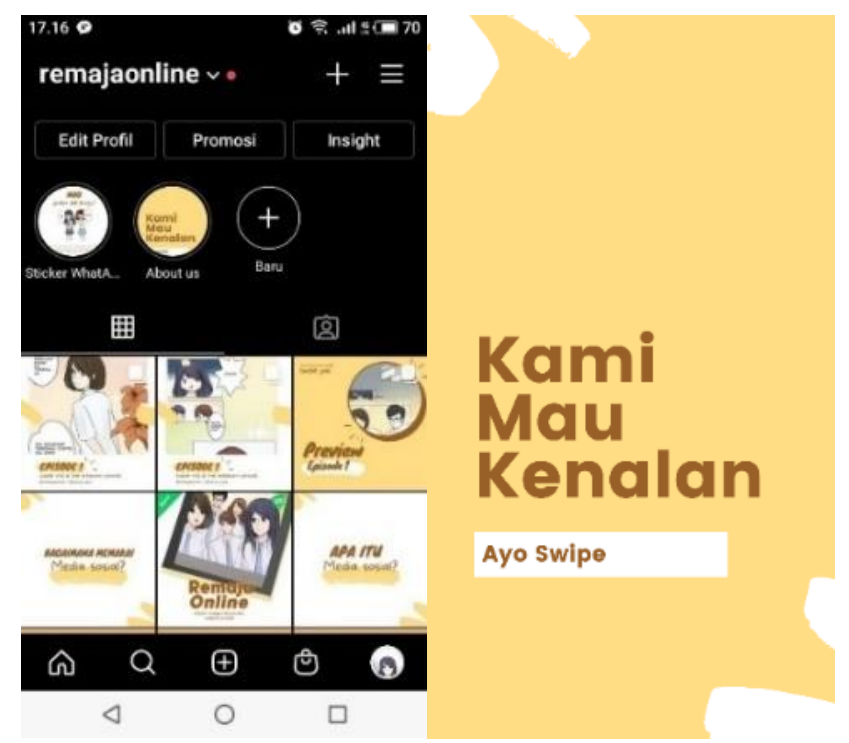

Gambar 10. Akun instagram dan story instagram komik" Remaja Online”.

\section{Botol Minum}

Merupakan media pendukung yang dapat dipakai remaja untuk menyediakan air minum ketika remaja berpergian ataupun bermain bersama teman-teman sebaya (Gambar 11).

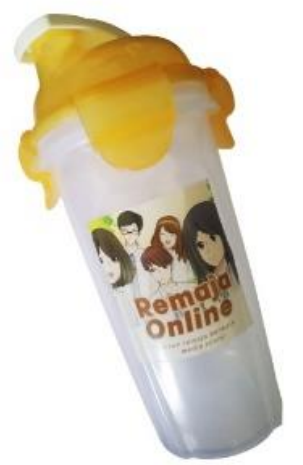

Gambar 11. Botol minum komik"Remaja Online".

\section{Tas totebag}

Totebag ini bergambar ilustrasi karakter komik dan berisi judul remaja online. Tas Totebag ini berwarna putih dan cocok untuk dipakai kalangan remaja baik laki laki maupun perempuan saat jalan-jalan karena memiliki bentuk desain yang simple (Gambar 12).

\section{Buku}

Merupakan media pendukung yang dipakai remaja untuk menulis poin-poin penting ketika belajar. Buku ini memiliki cover tokoh Remaja Online sebagai identitas visual berbahan kertas art paper 260gr sebagai cover dan kertas HVS 30 halaman sebagai isi buku (Gambar 13).

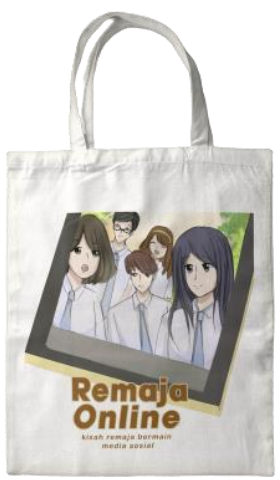

Gambar 12. Tas totebag komik"Remaja Online".

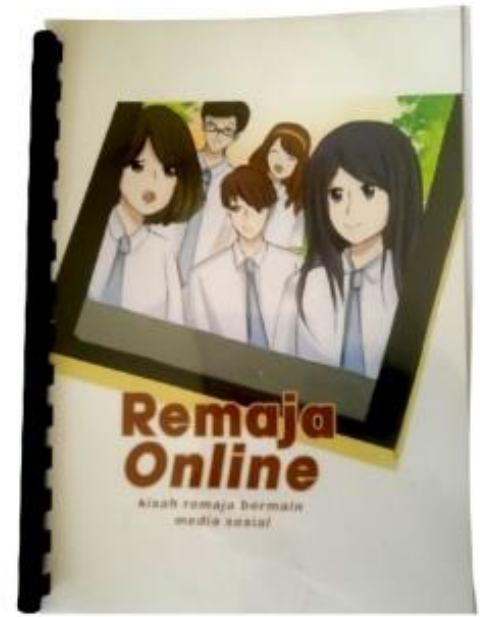

Gambar. 13. Buku tulis komik "Remaja Online".

\section{Sticker WhatsApp}

Adalah media promosi berupa sticker emosi berbentuk gambar format png yang berfungsi untuk mengungkapkan perasaan atau emosi ketika berkomunikasi bertukar pesan di WhatsApp.

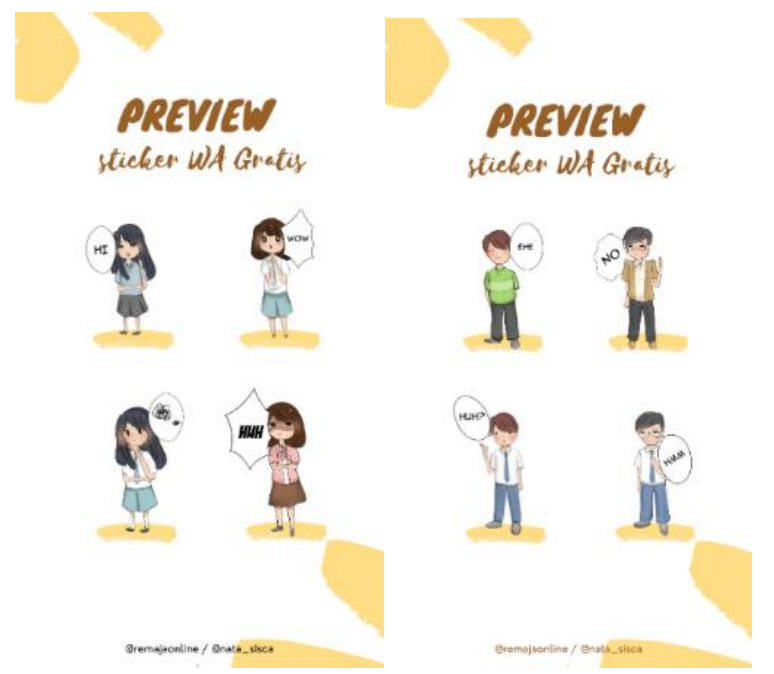

Gambar 14. Macam-macam sticker komik"Remaja Online".

Sticker whatsApp bisa didapatkan gratis melalui DM akun instagram "Remaja Online" 


\section{KESIMPULAN}

Fenomena remaja yang masih mengupload konten sensitif yang melanggar UU ITE menggambarkan bahwa remaja masih belum mengetahui cara menggunakan media sosial dengan bijak. Tujuan perancangan komik online ini yaitu untuk lebih meningkatkan pemahaman remaja tentang sikap hati hati dalam menggunakan media sosial melalui cerita komik tentang studi kasus dampak yang ditimbulkan bila remaja masih belum menggunakan media sosial dengan bijak serta mengajak remaja untuk mampu mengendalikan diri, emosi dan memahami poin-poin penting cara menggunakan media sosial dengan lebih bijak.

Diharapkan dengan dapat memanfaatkan hasil perancangan komik online ini akan dapat menarik remaja untuk membuat konten yang bersifat membangun di media sosial. Perancangan ini juga tak luput dari kekurangan dalam proses pengerjaannya yang dimulai dalam proses konsep cerita dan bentuk visual yang ditampilkan. Oleh karena itu, diperlukan pengembangan mengenai storytelling dan bentuk visual komik yang lebih rapi untuk menyesuaikan keinginan target pembaca komik ini. Dengan adanya pengembangan tersebut, diharapkan materi komik akan semakin mudah dipahami oleh para remaja.

\section{UCAPAN TERIMA KASIH}

Penulis mengucapkan terima kasih kepada seluruh pihak yang telah mendukung riset dasar perancangan komik online tentang cara mengunakan media sosial dengan bijak pada remaja usia 15-17 tahun, sehingga perancangan komik online ini dapat diselesaikan dengan lancar.

\section{DAFTAR PUSTAKA}

[1] Zulaiha, S., Sagiman, S., \& Mutia, M. (2019). Edukasi Literas Informasi Bagi Anak Dan Remaja Untuk Meminimalisir Penyalahgunaan Media Jejaring Sosial. Jurnal Harkat: Media Komunikasi Gender, 15(2), 116-125.

[2] Irawan, Aditya.W, Yusufianto. A, Agustina. D, dkk. (2020). Laporan Survei Internet APJJI 2019-2020 (Q2). (Asosiasi Penyelenggara Jasa Internet Indonesia). https://apjii.or.id/survei diakses tanggal 15 November 2020

[3] Felita, P., Siahaja, C., Wijaya, V., Melisa, G., Chandra, M., \& Dahesihsari, R. (2016). Pemakaian media sosial dan self concept pada remaja. Jurnal Psikologi Manasa, 5(1), 30-41.

[4] Tim detikcom (2020). Aksi Keblinger Remaja di NTB Salat sambil Joget Tik Tok. https://news.detik.com/berita/d-5004055/aksikeblinger-remaja-di-ntb-salat-sambil-joget-tiktok/3 diakses tanggal 12 oktober 2020

[5] Undang-Undang Republik Indonesia Nomor 11 Tahun 2008. Peraturan Informasi Dan Transaksi Elektronik. https://jdih.kominfo.go.id/produk_hukum/view/id/167/t/undangundan g+nomor+11+tahun+2008+tanggal+21+april++2008 daikses tanggal 12 oktober 2020

[6] Hakim, Alfian F. (2018). Pengembangan Komik Digital Sebagai Media Pembelajaran Alat-Alat Pembayaran Internasional Pada Materi Perekonomian Terbuka. Jurnal Pendidikan dan Ekonomi, 7 (3),204 205

[7] Muchlisin Riadi. (2020, Augustus 14). Komik (Pengertian, Unsur, Jenis dan Teknik Pembuatan): https://www.kajianpustaka.com/2020/08/komik-pengertian-unsurjenis-dan-teknik-pembuatan.html (15 Januari, 2021)

[8] Herviani, Vina dan \& Febriansyah, Angky .(2016) Tinjauan Atas Proses Penyusunan Laporan Keuangan Pada Young Enterpreneur Academy Indonesia Bandung. Jurnal Riset Jurnal Akutansi. 8 (2), (23)

[9] Rijali, Ahmad. (2018). Analisis Data Kualitatif. Alhadharah. Jurnal Ilmu Dakwah Uin Antasari. 19(2), 82-83

[10] Wikipedia Bahasa Indonesia (2021). Media sosial. https://id.wikipedia.org/wiki/Media_sosial (tanggal 15 Januari 2021) 